





\section{ZOOLOGICA}

SCIENTIFIC CONTRIBUTIONS OF THE NEW YORK ZOOLOGICAL SOCIETY

FROM THE TROPICAL RESEARCH

STATION IN BRITISH GUIANA

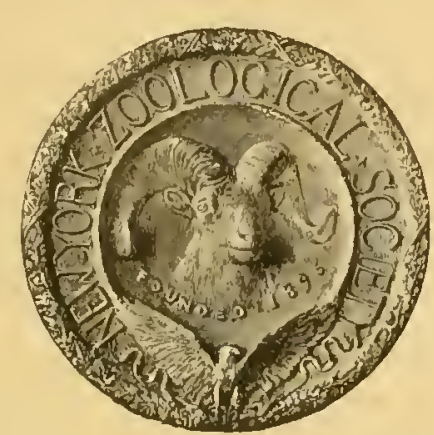

VOLUME III. NUMBER 10

(Tropical Research Station Contribution Number 104)

TWO TACHIGALIA MEMBRACIDS

By HeRBERT OSBORN

P U B L I S H E D B Y T H E S O C I E T Y THE ZOOLOGICAL PARK, NEW YORK

DECEMBER 24, 1921 



\title{
TWO TACHIGALIA MEMBRACIDS
}

\author{
By HERBERT OSBORN
}

Endoastus (?) productus sp. nov.

(Fig. 17.)

Head produced before the eyes, about as long as width between the eyes, distinctly furrowed above and below and bifid at tip, ocelli close to front margin of eye, antennæ below the eye in distinct sockets with raised margin; pronotum strongly convex, sloping to head, posterior angles subacute; scutellurn triangular slightly longer than basal width; elytra narrow, scarcely reaching end of abdomen; legs short cylindric, all of nearly equal length.

The color is uniformly dark brown except tibiæ, which are lighter, the surface of body and elytra densely and minutely punctured.

Female genital segment three times as long as preceding; the ovipositor extruded; male subgenital plate narrow, upcurved.

Length of female $5.5 \mathrm{~mm}$., of male $4 \mathrm{~mm}$.

This species has a more produced head than $E$. caviceps Fowl., but there seems to be no good structural character to warrant the formation of a distinct genus for it, and at least until the study of related species shows such distinction it seems proper to place it here.

Superficially it has a strong resemblance to the Cicadellids but in structural characters is obviously Membracid.

Eight specimens, seven females, one male. Kartabo, Bartica District, British Guiana, 1920, feeding on the terminal shoots of young Tachigalia trees. 

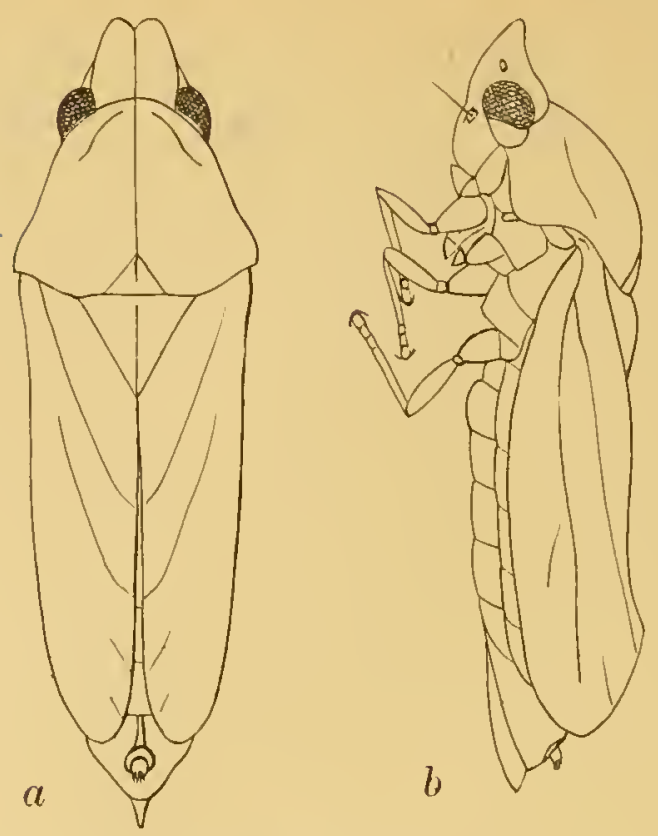

FIG. 17. ENDOASTUS (?) PRONUCTUS SP. NOV. FEMALE.

$a$, dorsal : $b$, lateral aspect.

Microcentrus (?) sp. Nymph.

A single nymph agreeing closely in structural characters with nymphs of Microcentrus sps. of Eastern U. S.

Body flattened, slightly convex above, head short, the anterior border with broad, fringed plates each side; abdominal segments 2-6 with flattened, fringed, plate-like expansions and the terminal segment broadly fringed. Length $6.5 \mathrm{~mm}$., widtn of thorax $3 \mathrm{~mm}$.

Feeding on the terminal shoots of young Tachigatia trees Kartabo, B. G., July, 1920. 


QL Wheeler, William Morton.

591 Study of some social

B74W48 beetles in British Guiana,

Ent. 1921. 


\section{|i |i || ||||||||||||||||| ||i|}

